\title{
THE READER'S DISCOURSE IN THE COGNITIVE AND NARRATIVE STRUCTURE OF A LITERTARY WRITING: RECEPTION AND INTERPRETATION IN THE AESTHETIC DIALOGUE
}

\section{Matsevko-Bekerska L. V.}

\section{INTRODUCTION}

The problem of the reader occupies the leading position in the modern literary criticism discourse and becomes a focus of increasingly active interest, undergoing dynamic transformation in terms of research methodology and projections on the framework of a literary text. In terms of cognitive aspects of artistic and aesthetic phenomenon, the sequence of presentation of all conceptual elements occurs as a self-sufficient communicative process. At the same time, its integrity and authenticity is ensured, above all, by the reader, who is ready for an appropriate aesthetic dialogue. Hence, the problem of the reader / reading is particularly relevant in the context of developing a methodology, in particular, for the cognitive and narratological study of both individual literary works and the author's style or certain parameters of poetics.

The unfolding of a plot or significant problematics has a temporal and spatial paradigm characteristic of the literary world. The kaleidoscopic change of depicted images and the transition from one temporal projection to the next one occur primarily due to the personalization of the world of the literary work in the mind of the reader. The cognitive aspect implies that, in accordance with the general precept, "sentences of utterances that appear in a literary work" that "are not proper judgments, but only quasijudgments, whose function is to give the depicted objects only a certain aspect of reality, should be perceived, without stamping them with reality". The temporal plane of a literary work is phenomenally implemented in the imagination of the reader, where events or different perceptions of one event are gradually overlaid. The cognitive process is aimed at performance of an integral image of the development of some phenomenon and it acquires a semantic completeness in the artistic work when synchronizing all events transformations, existing in the text or ascribed by the reader. Thus, the literary continuum from the fictional

\footnotetext{
1 Інгарден Р. Про пізнавання літературного твору. Слово. Знак. Дискурс: антологія світовоі літературно-критичної думки ХХ ст. / за ред. М. Зубрицької. Львів. Літопис. 2001. С. 179.
} 
plane in the author's conception - through imagination, thought, remembering and reproduction - moves into the mind of the reader. Subsequently, the work acquires a symbolic meaning, germinating additional meanings or their shades: "a work of verbal art, in contrast to its specification, is a schematic work. This means that some of its plans, especially the plans of presented objects, and the plan of images include "the places of non-delineation" ${ }^{2}$. In fact, the greatest receptive value of a literary and artistic work is the possibility of multiplication of meanings, the realization of an individual reader's understanding, which is entirely based on the continuum of meaning as defined by the author. The distance between the author and the reader increases in proportion to the schematization of the content of the work, and with the expression of the scheme, the reliability of each interpretation increases.

The presence of a literary work in the process of formation, development and implementation of artistic communication is directly correlated with the basic ways of expression of the reader. Unfolding of the text from one format of the reader's presence to another allows to express the aesthetic and ontological value of the work itself, as well as to understand the relation of the author's primacy in relation to the work, the work in relation to the reader or in return.

\section{Reception of a literary work: articulation of the dialogue}

According M. Zubrytska, "paradoxical perception of literary texts consists primarily in the fact that artistic communication by its nature and essence is both a complex social phenomenon and deep individualized, personally focused and intimately oriented process" 3 . The process of reception of the work, initiated by the first reading, is a kind of psychological projection of the personality of the reader. It is directly determined by the extra-literary context, as well as by the level of cultural and aesthetic integration of the individual into the coordinate system, which formats the consistency of both contemporary literature and the attitude and perception of the distant and axiologically different literature of the previous epoch (or epochs). Therefore, there is reason to analyze the reception environment as a concentration of expected reactions and probable estimates of a certain megapersonal community, as a way to implement the vision of literary discourse in its integrity and relevance to the temporal section in the historical sense. The cognitive plane of individual penetration into the meaning of a work is outlined primarily by the social factors, and only then one should observe the way of auto-reader's competence as such. Receptive

\footnotetext{
${ }^{2}$ Там само.

${ }^{3}$ Зубрицька М. Homo legens : читання як соціокультурний феномен. Львів. Літопис. 2004. С. 177.
} 
communication as the next link in the cognitive chain is less egocentric as compared to the first reading: if approaching the meaning rests solely on the empirical experience of the reader, as well as on his or her ability to respond to the author's suggestion, then reception is based on a relatively stable axiological paradigm. Analytical thinking mostly focuses on existing criteria and evaluations, differently verbalized, but invariably synchronous with the existence of artistic and aesthetic communication. We agree that "the artistic dimension is the text, the aesthetic dimension is the process of its perception, which is unthinkable without the subject of reception" ${ }^{4}$. Indeed, after the exhaustion of purely emotional contact, when the textual array is fully implemented, there comes a moment of cognitive and receptive comprehension / conceptualization - the text is filled with meaning(s), which are so heterogeneous, insofar as the intrinsic personal requests of each recipient are unique.

The semiotically encoded correlation of the real and fictional worlds in the process of penetrating into the semantic depth acquires different modifications; the allowed freedom of understanding has a considerable space for conjecturing meanings, the imaginary ascribing of attributive features and, of course, for the individualized by its own stereotype recognition of the work's images. A remark about the freedom allowed seems important enough in the discourse of reception of the work, since the first reading a priori is free from any restrictions and requirements. The involuntary emergence of figurative and conceptual contact between the text and the reader is beyond various obligations of the tolerant addressee of literary communication: suggesting of emotionally, intellectually or aesthetically meaningful sense relieves the reader of responsibility in front of the historicity of the author and in front of his or her own historicity for the level of established contact or the completeness of the transformed space. Instead, reception must design the evaluation criteria, taking into account the collective aesthetic experience and temporal extent of the work itself: "in the analysis of reception, the subject is an effect, rendered on the individual or collective reader, as well as on the text considered as an incentive" . Receptive activity should be much more careful than the first reading, though its result is also much more productive in terms of the meaning of the work. The reason is primarily the accumulation of knowledge about the text, about the work, about the author, as well as about the whole set of factors that have formed certain contours of literary communication. The peculiarity of literary and artistic discourse is that "one text is potentially capable of several different realizations, and no

\footnotetext{
${ }^{4}$ Там само. С. 37.

${ }^{5}$ Компаньйон А. Демон теории. М. Изд-во Сабашниковых, 2001. С. 174.
} 
single reading can ever exhaust all the potential possibilities, since each individual reader will fill in the gaps in the text on his/her own, eliminating many other possibilities; in the reading process he/she makes his own choice of how to fill the lacuna. In addition, it is in the act of this choice that the dynamics of reading is revealed. When making a choice, the reader openly acknowledges the inexhaustibility of the text, but at the same time it is the inexhaustibility that compels him/her to make his/her own choice" .

At the same time, one should think about the completeness of "gaps" or "lacunae" in the cognitive space. By exaggerating their multiplicity, we run the risk of losing touch with the original meaning of the work, creating a fictitious reception of the fictional world. A receptive scheme should predict the likelihood or presence of multiple readings of the text in terms of understanding its content and, in turn, offer the most optimal semantic paradigm. Characteristics and contextual knowledge of the author's historicity have the opportunity to bring the receptive efforts out of numerous hypothetical ideas about the literary work.

It is important that the next step after the first reading is synthetic by its nature and more complicated (from the standpoint of cognitive narratology) in implementation, since it must take into account rather unexpected turns in the perception and understanding of the literary work. As M. Zubrytska points out, "the forms of the reception process are not only articulation and verbalization, but also silence... Silence is not only an indispensable attribute of the reading process, it also has a significant functional purpose in the structure of the text - it increases the tension of the reception load, expresses the receptive background, identifies anomalies of the receptive landscape, or outlines the topology of the unspeakable. Silence favors the position of homo legens. It is the reader who otherwise "voices" the silence of the writing and brings to light from the depths of the text something that the author's imagination did not even foresee" . The paradox of literary dialogue is observed in the plane of being able to make individual contact - by and large, it is always the voice of one person. In the real sound of the author's speech, the verbalized portrait of the reader has no definition, the author's appeal is quite rhetorical. Encoded sense expects its understanding, but this hope is of approximate and desirable, but not mandatory nature, because cognitive synchronization cannot be provided by fictitious parameters. The receptive component of the process of reading the literary work is the voice of the

\footnotetext{
${ }^{6}$ Ізер В. Процес читання, феноменологічне наближення. Слово. Знак. Дискурс : антологія світової літературно-критичної думки ХХ ст. / за ред. М. Зубрищької. Львів. Літопис. 2001. С. 354.

${ }_{7}$ Зубрицька М. Homo legens : читання як соціокультурний феномен. Львів. Літопис. 2004. С. 327. 
reader only. Therefore, the full concentration of oneself in the matrix of the work, the depth of insight and approach to the author's challenge or invitation to dialogue is the responsibility of the reader. The silence of one of the interlocutors, in addition to waiting for some desired feedback, is important for formatting the openness of the conceptual space: "having the ability to concentrate a huge amount information on the "plane" of very short text, the artistic text has another feature: it gives different readers different information - as far as each of them understands, it also gives the reader a language that can be used to absorb the next batch of information when read again. It behaves like a living organism that feedbacks with the reader and trains this reader" ${ }^{\prime \prime}$. Thus, the silence of the author turns to a kind of cognitive polyphony of readers: being in a given ontological context, the reception is able to cover the circle of the most authentic variants of the meanings of the work. The first reading may be a competition for approaching the intention, but the reception must accumulate the author's intention as much as the author himself encourages and as much as much the reader's historicity requires an appeal to an omniscience of the meaning.

The problem of the cognitive specificity of the reception of the literary work is directly related to the concept of "a work in motion", characterized by U. Eco: "if you slowly rotate the lens of a polaroid, the projected figure begins to consistently change its colors, passing through the whole spectrum of rainbow colors and reacting through different chromatic layers of flexible materials in a series of transformations, which is manifested in the most flexible structure of the form. By rotating the lens at will, the recipient actually cooperates in the creation of an aesthetic object, at least within the field of possibilities, which determines the range of colors and the tendency of slides to flexibility" ${ }^{\text {" }}$. That is, if the author's voice focuses at some time on creating a dynamic and plastic artistic array, then the voice of the reader will be able to adequately interpret the creator's silence. Thus, the cognitive and receptive plane synchronizes the intentions for rooting the meaning in the text with the knowledge of that meaning, while leaving the author the right to hope for the understanding of the concept, and for the reader - the duty to listen to all explicitly or implicitly present "voices": of the author, of the context, of the historicity in the perception of the work by different readers, including different generations of readers. Being one-dimensional and personal at the time of artistic creation, the author's voice, as the beginning of literary communication, is gradually

\footnotetext{
8 Лотман Ю. Структура художественного текста. М. Искусство, 1970. С. 33.

${ }^{9}$ Еко У. Поетика відкритого твору. Слово. Знак. Дискурс : антологія світової літературно-критичної думки ХХ ст. / за ред. М. Зубрицької. Львів. Літопис. 2001. С. 534.
} 
split into numerous shades of sound: "it is risky to claim that a metaphor or poetic symbol, acoustic reality, or plastic form is a more perfect instrument of knowing reality than those offered by logic. Perceiving the world in science has its own permissible path, and every impulse of the artist towards insight, even when it is poetically fruitful, always has something ambiguous. In addition to the fact that art perceives the world, it also produces the addition of the world, revealing its own laws and living its own life. Every art form is best regarded, if not as a substitute for scientific knowledge, but an epistemological metaphor: that is, in every century the way of creating art form reflects through assimilation, metaphorization and concept image as such the way of seeing the reality by the science and culture of this particular era" $"$. The dialogue through the literary work always goes beyond the actual textual meaning - far beyond the horizons available at some point and thus increases the reader's receptive capacity. The process of reading after first acquaintance with a literary work undergoes much more noticeable and significant pressure of context, requires not only perception and accustoming to the artistic world, but the involvement of accessible intellectual and analytical tools to penetrate the content hidden in the text. At this stage, it is extremely important to assimilate the initial impression into a comprehensive understanding so harmoniously as not to lose the aesthetic appeal and uniqueness of the work, but also to articulate its meaning as accurately as possible. Thus, "how to reintegrate semantics into ontology without being affected by objections... Reflection is an intermediate stage in the direction of existence, in other words, the connection between understanding of the sign and self-understanding... With such an interpretation, I propose to overcome alienation, the distance between the past cultural age to which the text belongs, and self-understanding. Overcoming this distance, returning to understanding the text, exegesis can make sense; alienated, it can return to the true, in other words, to being; only by expanding the true self-understanding the Other can be understood. All hermeneutics is also, explicitly or implicitly, a self-understanding through the return to understanding the Other" ${ }^{\text {"11 }}$. Thus, if the first reading is a way to look for oneself-in-the-text (which provides outlining of cognitive horizon), the reception may be the search for a work-in-the-text (which enables the cognitive component dominate wool in the creation of meanings). The ability to balance the challenges of the author and the needs of the reader, the ability to truly project the author's silence on the voice of the reader,

\footnotetext{
10 Еко У. Поетика відкритого твору. Слово. Знак. Дискурс: антологія світової літературнокритичної думки ХХ ст. / за ред. М. Зубрицької. Львів. Літопис. 2001. С. 536.

${ }^{11}$ Рікер П. Конфлікт інтерпретацій. Слово. Знак. Дискурс : антологія світової літературно-критичної думки ХХ ст. / за ред. М. Зубрицької. Львів. Літопис. 2001. С. 298.
} 
and vice versa, the integrity of contextual knowledge - these and some other factors are considered most important for establishing the optimal receptive system, for finding the scheme of decoding the primary meaning of the literary work in the process of concretizing the cognitive chain.

\section{Interpretation of a literary work: \\ intellectual or aesthetic competition of the reader with the author}

The key question throughout the history of literary thought - from the mimetic conception of the Pythagoreans to structuralist attempts to draw a mosaic picture of meanings from disparate fragments - was to find, articulate, and maximize the way to exhaustively grasp the meaning of a work of art. The actual projection of the text, made during the first reading, gradually simulates the communicative situation, aimed both at updating the collective aesthetic experience and the search for individual personal reader's response to the invitation of the author for a dialogue. According to P. Ricœur, "interpretation... is the work of thought, which is to transform the sense of secret meanings into the revealed ones, showing the level of sense contained in the meaning of the literal one"12. The cognitive complexity of the interpretive effort is provided by the very essence of literary creativity: it is intended to transform the creative achievements of the author into the cognitive and aesthetic heritage of the addressee; it has in its internal structure the necessary prerequisites for establishing a productive meaningful dialogue. The quantitative space of the search for the true meaning of a work in real artistic communication is much greater than deliberately embedded and encoded by the author in the textual fabric. Each subsequent interpretation is caused by phenomenological factors, a considerable part of which cannot be either thoroughly investigated or detected by third-party observation by the very process of interpretation's unfolding. R. Jauss reasonably concludes that "the reconstruction of another's semantic horizon is, for the most part, not entitled in practice... to have a form of assimilation of the interpreter's own horizon (as the first anticipation) with the interpreted horizon" $"$. After all, in the practical contact of the reader with the work, the aesthetic, and subsequently intellectual and axiological competition for the primacy in imposing an understanding of the primary meaning of the work occurs. If, at first reading, this dominance is acquired by the reader, if in the process of reception the author's silence is actualized and through the text it acquires

\footnotetext{
12 Рікер П. Конфлікт інтерпретацій. Слово. Знак. Дискурс : антологія світової літературно-критичної думки ХХ ст. / за ред. М. Зубрицької. Львів. Літопис. 2001. С. 295.

13 Яусс Г. Р. Естетичний досвід і літературна герменевтика. Слово. Знак. Дискурс : антологія світової літературно-критичної думки ХХ ст. / за ред. М. Зубрицької. Львів. Літопис. 2001. С. 377.
} 
expressiveness and comprehension, then interpretation must harmonize the holistic communication. Intellectual activity, aimed at decoding the meaning of a literary work, inevitably takes into account the personal need of the reader to add to the primary meaning the data, situationally important for him/her. According to M. Zubrytska, "the process of reading and understanding an artistic text is often influenced by two factors: the asceticism of human feelings and their excess" ${ }^{14}$.

Accordingly, the psychological instruction of the reader largely guides the interpretation: the lack of individual cultural experience or its insufficiency gives the right to understand the meaning of the work as intended by the author; on the other hand, a perfect reading competence suppresses the author's intention and offers its own semantic basis for the system of meanings in the work. In fact, this approach to the differentiation of the interpretation space allows for the ambiguity of assimilation of meanings or horizons (according to Jauss). As the text becomes an object of the cognitive and aesthetic dialogue with different levels of recipient's readiness, the quality of the assimilation process is also different. It is known that "the listener can understand much better than the speaker what is hidden behind the word, and the reader can understand the idea of the work better than the author. The essence, the power of such a work is not in the way the author understood it, but in the way it acts on the reader or the viewer" ${ }^{\text {" }}$. That is, attribution of meaning to the text is a psychological attempt of the reader to perform interpretation according to his/her vision, according to those stereotypes that have formed in his/her mind long before the acquaintance with a certain verbal continuum. Obviously, "the text is a potential plan on the basis of which the reader, in the course of interaction, builds a coherent and holistic object" ${ }^{\prime \prime}$. Interpretation thus goes beyond a given method of literary studies, as it promotes the self-identity of the addressee, as well as his/her involvement in a global communicative network that unfolds in the cognitive space. Undoubtedly, "a work of art is a form completed and closed in its perfection of a balanced organism, and at the same time it is open to the possibility of being interpreted in various ways without the danger of losing its uniqueness. Therefore, every "consumption" of a literary work is its interpretation and realization, because in each subsequent vision the work comes to life again and again in a distinctive perspective" ${ }^{, 17}$. However, despite every new revival of the meaning of the work, all the nuances of understanding are not entirely

\footnotetext{
14 Зубрицька М. Homo legens : читання як соціокультурний феномен. Львів. Літопис. 2004. С. 99.

15 Потебня А. Из записок по русской грамматике. М. : Учпедгиз, 1958. Т.1. С. 140.

16 Зубрицька М. Homo legens : читання як соціокультурний феномен. Львів. Літопис. 2004. С. 175.

17 Еко У. Поетика відкритого твору. Слово. Знак. Дискурс: антологія світової літературнокритичної думки ХХ ст. / за ред. М. Зубрицької. Львів. Літопис. 2001. С. 527.
} 
autonomous, and therefore the complex of interpretations grows, and it is not only modified as a one-time perception or understanding. In the real dialogue with the reader of the literary work, the original meaning absorbs the sum of the previous ones as relative to the moment of feedback. The transformation of meaning occurs synchronously with changes in the reader's possibilities. Of course, "the semantic possibilities of the text will always remain richer than any configurable meaning that is produced in the reading process" 18 , but a responsible interpretation gradually narrows "the places of non-delineation". On the one hand, the individual response to the textual structures differs from others, on the other - there is a risk of being too far from the specific semantic continuum of the work. The radius of action for the reader to conjecture the meanings is always delineated, it should not be ignored, and one should not assume the right to comprehend at the expense of losing the inherent worth. The presence of interpretation in comparison with the work itself is appropriate, at the same time the intentionality of the author is indisputable. Therefore, the search for a way of interpretation or its initial position should be based on the reader's guess about the conception of the work, and only then it should be projected on his/her assumption as to the new meanings. According to U.Eco, "different interpretations - existentialist, theological, clinical, psychoanalytical... are limited only in the sphere of possibilities of the work. In fact, the work remains inexhaustible and open because it is "ambiguous" after the orderly world, established in accordance with universal laws, is displaced by a world based on ambiguity. The absence of orientation centers denies such a work, and new attempts at exploring the meanings confirm it. Sometimes it is difficult to ascertain whether the author had a certain symbolic concept, a tendency for uncertainty or ambiguity" 19 . For interpretation as a component of cognitive discourse, it is not the author's principle of reading behavior that is fundamental. The rooting of polyphony in the text obviously aspires for, but does not require to be literally heard or, moreover, to be understood. It only completes the fact that there are numerous permissions for the reader in the matrix. An important achievement of the dialogical history of a particular text is the comprehension in the process of interpretation of the proposed, if not consciously by the author, the specific historicity of the possibilities of understanding. It is worth agreeing that "the way of gaining experience through the text reflects the reader's personal inclinations, and then the literary text functions as a kind of mirror, but at the same time the reality

\footnotetext{
18 Ізер В. Процес читання, феноменологічне наближення. Слово. Знак. Дискурс : антологія світової літературно-критичної думки ХХ ст. / за ред. М. Зубрицької. Львів. Літопис. 2001. С. 358.

${ }^{19}$ Еко У. Поетика відкритого твору. Слово. Знак. Дискурс : антологія світової літературно-критичнӧ̈ думки ХХ ст. / за ред. М. Зубрицької. Львів. Літопис. 2001. С. 531.
} 
that this process helps to create differs from its vital reality. Thus, we have a somewhat paradoxical situation in which the reader is forced to discover aspects of his/her self in accordance with the experience of reality, which is different from the reality in which he/she abides. The impact of this reality will largely depend on how well he/she provides himself/herself with an unwritten piece of text, and until the reader fills in the missing links, he/she must think in a language of experience other than his/her own. It is clear that only by anticipating the world of his/her experience the reader can really participate in the events of the literary text by offering himself/herself to its disposal" ${ }^{, 20}$. The process of interpretation serves to establish the cognitive and communicative discourse, first and foremost, in the circle of personal associations, that is, in the course of dialogue, when the work is silent. The next step towards understanding the meaning is the reader's projection of the author's voice onto the textual array and the assumption of probable meanings of the written. If there are pauses of any level in the literal sound of the artistic world - whether thematic, imaginative or emotional - the reader inadvertently fills the supposed void. Over time, in the process of reading, the number of such obscure places reduces, the semantic consistency of the work is condensed not only due to the readers' guesses and assumptions, but also by the knowledge of the original design. Indeed, "we can only imagine what is not present here, the written part of the text gives us information, and the unwritten one gives us the opportunity to imagine things; but, of course, without the elements of uncertainty and the presence of lacunae in the text, we are unable to use our imagination" 21 . If the interpretative strategy is as closely as possible correlated with the original meaning of the work, then the text will offer less "elements of uncertainty" every time, but this does not deprive the reader of the right to "his/her work". The difference will only be in the format of the imaginary world - whether it will be derived from the fictional world in its conception, or it will become an analogy to the fictional one, which is actually represented in a particular work.

In addition to silence as a powerful element of literary communication, a significant place belongs to the inherent attribute of the reader's activity - the psychological illusion of perception of the artistic world, which naturally grows from the intrinsic illusory nature of the author's intention: "without creating illusions, the unknown world of text remains unknowable, and through illusions, the experience offered by the text becomes accessible to us, and only because illusions exist at different

\footnotetext{
${ }^{20}$ Ізер В. Процес читання, феноменологічне наближення. Слово. Знак. Дискурс : антологія світової літературно-критичної думки ХХ ст. / за ред. М. Зубрицької. Львів. Літопис. 2001. С. 355.

${ }^{21}$ Там само. С. 356.
} 
levels of its consistency does the experience of the text become "readable"... The text provokes certain expectations, which we project on it, reducing the polysemantic possibilities to the only possible interpretation consistent with expectations caused and thus choose individual configurative meaning. The polysemantic nature of the text and the construction of the illusion by the reader are oppositional factors... Both extremes are permissible, but in the individual literary texts, we will always find separate forms of balance between two conflicting tendencies. The creation of illusions cannot be holistic and, in fact, incomplete and their productive value consists in this incompleteness" 22 . The right of the reader to cognitively summarize aesthetic information is identical to the processual restriction of illusions in textual perception. High expectations for the content or figurative structure in a real dialogue are obtained first and foremost for the reader's revision. The influence of the artistic system is manifested either in the confirmation of expectation, or in its modifications, or in the destruction of the imaginary expectation. If the beginning of reading is a complete appropriation of the textual array in meaningless relationships and intertwining of senses, then the interpretation sets the rules for a "great creative game" with the text. In the polyphonic voice of a literary work, the reader has the opportunity to hear all the voices, many voices or some single voices. Expanding the space of the experienced, felt, listened and perceived makes the interpretation much closer to the author's intention, while giving the reader the choice -either to limit the satisfaction of expectations, or to try to transform the literary work into an object of pleasure. According to $\mathrm{Yu}$. Lotman, "one must abandon the traditional notion that the world of denotation of the secondary system is identical with that of the world of the primary one. The secondary modeling system of the artistic type constructs its own denotation system, which is not a copy, but a model of the world of denotates in the general linguistic sense" ${ }^{\text {23 }}$. Thus, interpretation must implement the cognitive component: to differentiate between the fictionality of the depicted world and the originality of the world that is known by the reader. The activity of the analytical mechanism focuses on establishing the obvious connections of what is perceived directly and formed as an emotional impression, with what is objectively embedded in the content of the work. Even if not identified, the synchronization of both modeling systems is a key to successful interpretation, since the autonomous existence of two distinct structures with individual meaning in

\footnotetext{
${ }^{22}$ Ізер В. Процес читання, феноменологічне наближення. Слово. Знак. Дискурс : антологія світовоі літературно-критичної думки ХХ ст. / за ред. М. Зубрицької. Львів. Літопис. 2001. С. 357.

${ }^{23}$ Лотман Ю. Структура художественного текста. М. Искусство, 1970. С. 61.
} 
a common textual space can bring perception of a particular work to the level of polar-oriented communication. That is, insisting on the right to attribute the meaning of a work to each participant in the dialogue without taking into account the probable projections to the plane of perception by the interlocutor may quite logically end in a conflict of understanding the meanings, and subsequently - the inability of communication around the same work. In fact, the process of interpretation, as well as the process of reading, is caused by two key aspects that are present in the text: "the first is the repertoire of well-known literary samples and periodical literary topics together with allusions to a familiar social and historical context, and the second involves technique and strategy, which is used to establish the relation between the known and the unknown. Elements of the repertoire are constantly relegated to the background or put forward in the foreground with equally effective enhancement, triviality or even elimination of allusions" 24 . The interpreter's efforts center around the ways of cognitively harmonizing the "repertoire" with "technique" and "strategy". For this stage of the study of meaning, the level of ownership of the context is important, since the search for the hidden meaning must first and foremost be different from the available meanings, and those, in turn, are determined by the horizon of the author's experience. Therefore, interpretative discourse is a form of sounding the complex layers of cultural and historical significance. It synthesizes not only the meaning of a particular literary work, but also defines, models and tends to direct the whole process of aesthetic communication with the same level of presence of the real and the fictional. According to U. Eco, "text is a mechanism that has the task of producing its exemplary reader... Text can provide an exemplary reader who has the right to test an infinite amount of speculations. An empirical reader is just a performer who makes a guess about the exemplary reader, provided by the text. Since a textual intention is, in essence, a production of the Exemplary Reader, capable of formulating assumptions about it, the initiative of the Exemplary Reader is the invention of the Exemplary Author, who does not identify with the empirical author, but only with the intention of the text" ${ }^{25}$. The main mission of interpretation in the discourse of the cognitive process seems to bring the psychological configurations of the reader somewhat closer to the author's real and imagined personalities. Only by entering into a "common language" of the literary work and the reader will it be possible to know the true meaning of the artistic phenomenon. In fact, "reading a literary

\footnotetext{
${ }^{24}$ Ізер В. Процес читання, феноменологічне наближення. Слово. Знак. Дискурс : антологія світової літературно-критичної думки ХХ ст. / за ред. М. Зубрицької. Львів. Літопис. 2001. С. 365.

${ }^{25}$ Еко У. Надінтерпретація текстів. Слово. Знак. Дискурс : антологія світової літературно-критичної думки ХХ ст. / за ред. М. Зубрицької. Львів. Літопис. 2001. С. 561.
} 
work occurs in the midst of a constant fluctuation that leads from the work to inspired authentic codes, and from there to the attempt to read the work correctly, and again to our own codes and dictionaries in order to test them on this communicant. After that, we are constantly mapping and combining different keys while enjoying the work due to its vagueness, which is caused by the surprisingly decent use of features compared to the source code and the surprisingly decent use of the meaning as compared to our target codes. Any interpretation of the work, filling with new meanings the empty and open form of primary communicant (a physical form that has been kept unchanged for centuries), gives rise to new communicants meanings that enrich our codes and our ideological systems, rebuild them and make it possible to adopt a new interpretation position in terms of the work - all of which is in constant motion, which is constantly renewed, a movement whose specific future forms it [semiology] cannot predict" 26 . Movement around the conceptual center of the literary work is always limited in the space of the author's design. Each new or subsequent guess about meaning is a reflection of the reader's initiative to find or imagine their own environment of conjecturing the meanings.

\section{CONCLUSIONS}

Despite the multiplicity and complexity of integrated interpretation of aesthetic and artistic phenomenon, the cognitive aspects of scientific discourse make it possible to observe the sequence, integrity of perception and close pursuit of the primary matrix of the meaning in the literary work. Unraveling the semiotic nature of an image or symbol occurs according to the rules set by the interpreters themselves, that is, the imaginary meanings are first formulated and then they acquire value in the format of understanding. The integrity of the cognitive chain makes it possible to avoid the loss or incredible distance from the setpoint, so a perfect interpretation as the completion of the receptive process should take into account all probable and valid challenges of the text. An important fact is that each interpreter is primarily the reader, therefore the prospect of understanding has a clear individualized direction - it relies on the cognitive and emotional perception, which is later defined as coordinates of evaluative attitude, and further - becomes the basis for formatting the analytical research process. As W. Iser shrewdly points out, "the production of the meaning in literary texts that we discuss in connection with the formation of "gestalt" of the text does not always lead to the discovery of the unknown, which can be used by the active imagination of

\footnotetext{
${ }^{26}$ Еко У. Реторика та ідеологія. Слово. Знак. Дискурс : антологія світової літературно-критичної думки ХХ ст. / за ред. М. Зубрицької. Львів. Літопис. 2001. С. 543.
} 
the reader, but sometimes causes the possibility of self-expression and thus the discovery of what has recently diverged from our understanding. These are the ways in which reading literature gives us a chance to speak of not yet spoken" $" 27$.

Even if we refuse to attempt the complete cognitive assimilation of the horizons of the author and the reader, we must leave at least a partial opportunity to agree the author's invitation for concordance and the real response of the reader to that invitation. Any interpretative strategy must tolerate the Other with all objectively available and individually desirable rights to the meaning of the work. For interpretation, it becomes inevitable to split projections of the meaning of the work, because it is necessary to provide for the formatting of all-possible circles of intention presentation, which combines textual fragments into a semantic unity: "a shift in focus to the figure of the author on the text and through the text on the reader inevitably led to the assumption: if the author's intention takes on more blurred outlines and is not essential in the interpretative process, then the meaning belongs to the text and is in context, and therefore it has four important dimensions: temporality, subjectivity of the researcher (recipient), referentiality, interactive form of communication" ${ }^{\text {"28. In each }}$ method of interpretation, these dimensions of meaning are interwoven into unique configurations of a literary polylogue. Beyond the conscious effort of the reader to abstract from the biographical experience of the author and, having removed the demiurge's directives, to get an imaginary rise above the world of the work of art, there is a compelling format of understanding where the reader is able to see what the author showed, what the author wanted to show and showed involuntarily, or what the author tried to conceal, but what was able to find a niche in the textual space. With increasing temporal distance of the work from its historicity, interpretative efforts have a much larger analytical perspective: numerous accumulations of values maximize the mosaic structure of the text into the self-sufficient sense-making concepts, allowing to vary the interpretive model, and then to build up another paradigm of meanings of the literary writing.

\section{SUMMARY}

The issue of the place and role of the reader in the process of aesthetic communication attracts the attention of literary critics of different directions. In particular, for narratological discourse, it seems important to find out the features of the reader's presence in the presentation of the

\footnotetext{
${ }^{27}$ Ізер В. Процес читання, феноменологічне наближення. Слово. Знак. Дискурс : антологія світової літературно-критичної думки ХХ ст. / за ред. М. Зубрицької. Львів. Літопис. 2001. С. 365.

28 Зубрицька М. Homo legens : читання як соціокультурний феномен. Львів. Літопис. 2004. С. 68-69.
} 
story, in particular at the stage of its perception and comprehension. First of all, from the standpoint of disclosing the specifics of presentation in a literary work, the psychological prerequisites of communication with the reader are considered.

From the point of view of cognitive aspects of the artistic and aesthetic phenomenon existence, the sequence of presentation of all conceptual elements of the literary work occurs as a self-sufficient communicative process. At the same time, its integrity and authenticity is ensured, above all, by the reader, who is ready for an appropriate aesthetic dialogue. Therefore, the problem of the reader / reading is particularly relevant in the context of developing a methodology, in particular, for cognitive and narratological study of both individual literary works and the author's style or certain parameters of poetics.

\section{REFERENCES}

1. Еко У. Надінтерпретація текстів. Слово. Знак. Дискурс : антологія світової літературно-критичної думки $X X \mathrm{~cm}$. / за ред. М. Зубрицької. Львів. Літопис. 2001. С. 549-563.

2. Еко У. Поетика відкритого твору. Слово. Знак. Дискурс : антологія світової літературно-критичної думки $X X \mathrm{~cm}$. / за ред. М. Зубрицької. Львів. Літопис. 2001. С. 525-538.

3. Еко У. Реторика та ідеологія. Слово. Знак. Дискурс : антологія світової літературно-критичної думки $X X \mathrm{~cm}$. / за ред. М. Зубрицької. Львів. Літопис. 2001. С. 539-548.

4. Зубрицька M. Homolegens: читання як соціокультурний феномен. - Львів: Літопис, 2004. 352 с.

5. Ізер В. Процес читання, феноменологічне наближення. Слово. Знак. Дискурс : антологія світової літературно-критичної думки XX cm. / за ред. М. Зубрицької. Львів. Літопис. 2001. С. 349-368.

6. Інгарден Р. Про пізнавання літературного твору. Слово. Знак. Дискурс : антологія світової літературно-критичної думки ХХ ст. / за ред. М. Зубрицької. Львів. Літопис. 2001. С. 176-208.

7. Компаньйон А. Демон теории. М. Изд-во Сабашниковых. 2001. $307 \mathrm{c}$.

8. Лотман Ю. Структура художественного текста. М. Искусство. $1970.384 \mathrm{c}$.

9. Потебня А. Из записок по русской грамматике. М. Учпедгиз. 1958. T.1. C. 140.

10. Рікер П. Конфлікт інтерпретацій. Слово. Знак. Дискурс : антологія світової літературно-критичної думки $X X \mathrm{~cm}$. / за ред. М. Зубрицької. Львів. Літопис. 2001. С. 288-304. 
11. Яусс Г. Р. Естетичний досвід і літературна герменевтика. Слово. Знак. Дискурс : антологія світової літературно-критичної думки XX ст. / за ред. М. Зубрицької. Львів. Літопис. 2001. C. 368-405.

Information about the author: Matsevko-Bekerska L. V., Doctor of Philological Sciences, Associate Professor, Head of the World Literature Department, Faculty of Foreign Languages, Ivan Franko National University of Lviv 1, Universytetska str., Lviv, 79000, Ukraine 